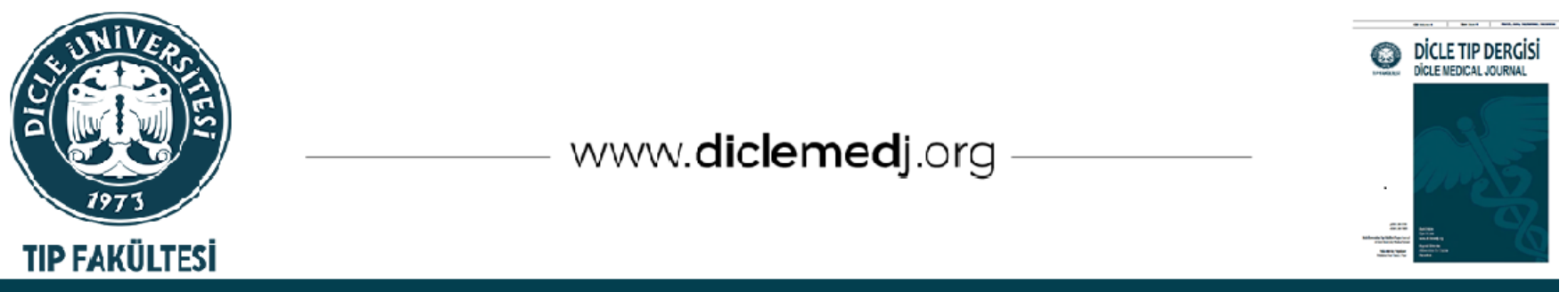

Original Article / Özgün Araştırma

\title{
Evaluation of the right and left ventricular functions of patients that recovered from COVID-19 at home
}

\author{
Abdulmecit Afşin ${ }^{i}{ }_{1}$, Arif Süner ${ }^{i D_{2}}$, Yusuf Hoşoğlu ${ }^{\text {iD }}$, Ayşe Hoşoğlu ${ }^{\text {iD }} 1$ \\ 1 Department of Cardiology, Adiyaman Training and Research Hospital, Adiyaman, Turkey \\ 2 Department of Cardiology, Adiyaman University Faculty of Medicine, Adiyaman, Turkey
}

Received: 29.06.2021; Revised: 13.09.2021; Accepted: 15.09.2021

\begin{abstract}
Objective: Coronavirus disease 2019 (COVID-19) is an infection that can involve various systems and organs, as well as the cardiovascular system. There are several reports in the literature on cardiac involvement in COVID-19 patients who are hospitalized. Therefore, the current research was designed to determine whether cardiac involvement occurred in COVID-19 patients at home.

Methods: The current research included 30 patients with a positive COVID-19 PCR test but no hospitalization and recovery at home, and also 30 healthy volunteers. All participants underwent routine and transthoracic echocardiographic exams. The left and right ventricular diameters and functions were examined using two-dimensional echocardiography. M-mode imaging was used to assess tricuspid annular plane systolic excursion (TAPSE) and mitral annular plane systolic excursion (MAPSE). In addition, the tissue Doppler images of the patients were recorded.
\end{abstract}

Results: In the COVID-19 group, $53 \%$ of the patients were male, and the mean age was 35.6 years $( \pm 7.6)$. The control group consisted of $57 \%$ males, and the mean age was 35.1 years $( \pm 6.9)$. The right and left ventricular diameters, systolic pulmonary artery pressure, and TAPSE and MAPSE values were similar in the two groups. In both groups, the tricuspid lateral annular systolic velocity ( $S^{\prime}$ tricuspid) values were in the normal reference range. However, the $S^{\prime}$ tricuspid value was statistically lower in the COVID-19 group than in the control group (13 [14-11] vs. 14 [15-13]; p=0.010).

Conclusion: In this study, cardiac functions did not significantly differ between patients with mild COVID-19 infection and the control group.

Keywords: Coronavirus disease 2019, home recovery, cardiac involvement, ventricular function

DOI: 10.5798/dicletip.1001933

Correspondence / Yazışma Adresi: Arif Süner, Department of Cardiology, Adiyaman Training and Research Hospital, Adiyaman, Turkey e-mail: arifsuner@gmail.com 


\section{Ayaktan COVID-19 geçiren hastaların sağ ve sol ventrikül fonksiyonlarının değerlendirilmesi}

Öz

Amaç: Coronavirüs hastalığı 2019 (COVID-19), kardiyovasküler sistemin yanı sıra çeşitli sistem ve organları tutabilen bir enfeksiyondur. Literatürde hastaneye yatırılan COVID-19 hastalarında kardiyak tutulum ile ilgili çeşitli raporlar bulunmaktadır. Bu nedenle, mevcut çalışmanın amacı, evde iyileşmiş COVID-19 hastalarında kalp tutulumunun olup olmadığını değerlendirmektir.

Yöntemler: Bu çalışmaya COVID-19 PCR testi pozitif olan ancak hastanede yatışı olmamıș, tedavisi evde alıp iyileşen 30 hasta ile 30 sağlıklı gönüllü dahil edildi. Tüm katılımcıların rutin ve transtorasik ekokardiyografik muayeneleri yapıldı. İki boyutlu ekokardiyografik olarak her iki ventrikül boyutları ve fonksiyonları incelendi. Triküspit kapağın anüler planda sistolik yer değiştirmesi (TAPSE) ve mitral kapağın anüler planda sistolik yerdeğiștirmesi (MAPSE)'yi değerlendirmek için M-mod görüntüleme kullanıldı. Ek olarak, hastaların doku Doppler görüntüleri kaydedildi.

Bulgular: COVID-19 grubunda hastaların \%53'ü erkek olup, yaş ortalaması $35.6( \pm 7.6)$ idi. Kontrol grubunun \%57 erkek olup, yaș ortalaması $35.1( \pm 6.9)$ idi. Sağ ve sol ventrikül çapları, sistolik pulmoner arter basıncl, TAPSE ve MAPSE değerleri iki grupta benzerdi. Her iki grupta da triküspit lateral anüler sistolik hız ( $S$ ' triküspit) değerleri normal referans aralığındaydı. Bununla birlikte, S' triküspit değeri COVID-19 grubunda kontrol grubuna göre istatistiksel olarak daha düşüktü (13 [14-11]'e karşı 14 [15-13]; p=0.010).

Sonuç: Bu çalışmada, COVID-19 enfeksiyonu hafif geçiren hastalar ile kontrol grubu arasında kardiyak fonksiyonlarda anlamlı farklılık bulunmadı.

Anahtar kelimeler: Koronavirüs hastalı̆̆ 2019, evde iyileşme, kardiyak tutulum, ventrikül fonksiyonları.

\section{INTRODUCTION}

While more than one year has passed after the outbreak of COVID-19, the pandemic is still causing significant morbidity and mortality worldwide ${ }^{1}$. Numerous researches have statemented that patients with COVID-19 have cardiac involvement and consequently develop myocardial damage ${ }^{2}$. In addition, different cardiovascular complications owing to COVID19 , such as acute myocardial infarction, acute myocarditis, decompensated heart failure, and arrhythmia have been described in previous case series ${ }^{3}$. Transthoracic echocardiography is a rapid, affordable, and widely available test for both right and left ventricular (RV and LV) function. In a retrospective study, it was observed that $55 \%$ of patients hospitalized due to COVID-19 had abnormal echocardiography findings ${ }^{4}$. Another study showed that RV dilation and dysfunction in $39 \%$ of patients, accompanied by $\mathrm{LV}$ diastolic dysfunction in $16 \%$, and by LV systolic dysfunction in 10 percent were the most common cardiac pathologies in patients hospitalized with the COVID-19 disease 5 .

Mitral annular plane systolic excursion (MAPSE) is a linear echocardiographic measurement that assesses longitudinal LV function. MAPSE has been shown to predict mortality in critically ill COVID-19 patients 6 . Tricuspid annular plane systolic excursion (TAPSE) is a specific and easily quantifiable parameter that shows global RV function and describes apical to basal shortening7. It is known that TAPSE is closely related to RV ejection fraction $(E F)^{8}$. Furthermore, in a study comprising patients hospitalized because of COVID-19, it was observed that RV and LV functions were impaired and decreased TAPSE was associated with in-hospital mortality related to the disease ${ }^{9}$.

Echocardiographic studies in COVID-19 have generally been undertaken in hospitalized patients. There are only a few studies in the literature evaluating RV and LV functions in 
patients who have had a positive COVID-19 test without requiring hospitalization. It is important to determine the effect of COVID-19 on $\mathrm{LV}$ and $\mathrm{RV}$ in patients with a mild clinical course who have recovered from the disease after treatment at home. The purpose of our study was to compare echocardiographic findings (RV and LV function) in patients who had a positive PCR test for COVID-19 and finished their treatment at home to healthy individuals of similar age and gender.

\section{METHODS}

\section{Study design}

The research was conducted in our tertiary outpatient clinic between January and February 2021 as a prospective cross-sectional study. The study included patients who presented to the cardiology outpatient clinic for a variety of reasons, who had previously a positive COVID19 PCR test without hospitalization, and completed their treatment at home. Furthermore, as the control group, healthy volunteers of similar age and sex who presented to the cardiology outpatient clinic for various reasons and had no organic or mental disease were evaluated. Individuals with ischemic heart disease, chronic obstructive pulmonary disease, myocarditis, valvular heart disease, pulmonary hypertension, malignancy history, heart failure, immunodeficiency, liver and kidney failure were excluded. In addition, those who had had COVID-19 PCR test positivity earlier than three months (time from the date of diagnosis to presentation) were excluded. Individuals over 55 years old were excluded considering that diastolic dysfunction can develop due to cardiac stiffness in those over 55 years of age $\mathrm{e}^{10}$.

\section{Study protocol}

The date of COVID-19 diagnosis was used as the index date for determining the appropriate timing of echocardiography, which was performed after a median of 39 [60-26] days. Transthoracic echocardiographic evaluations were performed for all participants using the Vivid S6 echocardiography device (GE, Norway) and 2.5-3.25 $\mathrm{MHz}$ transducer in accordance with the guidelines published by the American Echocardiography Society ${ }^{10,11}$. Twodimensional (2-D), pulsed wave Doppler (PWD), tissue doppler imaging (TDI) and Mmode analyses were performed with the patients in the supine position and left lateral lay.

\section{Assessment}

The interventricular septum thickness (IVS), posterior wall thickness (PW), and left ventricle end-diastolic dimension (LVEDD) were determined at end-diastole from the parasternal long-axis view. The left atrium (LA) diameter and LV end-systolic dimension (LVESD) were assessed at end-systole from the parasternal long-axis view. The modified Simpson method was utilized to measure the LVEF. LV dysfunction was defined if LVEF < $50 \%$. LV mitral inflow velocities were determined using PWD from apical fourchamber view. The E/A ratio was computed by recording the mitral early (E) and late (A) diastolic velocities from the apical transducer position of the sample volume located between the mitral leaflet tips. TDI recordings were acquired from the apical four-chamber view. While conducting the TDI examination, the Nyquist limit was set to $15-20 \mathrm{~cm} / \mathrm{sec}$, and the sampling volume width was adjusted to $2 \mathrm{~mm}$. Peak myocardial early diastolic velocity ( $\left.\mathrm{e}^{\prime}\right)$ and myocardial late diastolic velocity (a'), and myocardial systolic velocity $\left(S^{\prime}\right)$ were computed from the mitral lateral (e'lat, a'lat, S'lat,) and septal annulus (e'sept, a'sept, S'sept). M-mode echocardiography was used to measure MAPSE in the apical four-chamber views. Then, mitral lateral (MAPSE lat) and septal annulus (MAPSE sept) were calculated ${ }^{11}$. 


\section{RV Assessment}

The RV basal and mid diameters were measured at end-diastole using an apical four-chamber view. Pulmonary systolic (sPAP) arterial pressure was calculated using the Bernoulli equation modified from the tricuspid jet's maximum velocity (TR) and the right atrium pressure predicted from inferior vena-cava size and collapsibility. TAPSE was calculated using M-mode imaging and was defined as the systolic displacement of the lateral tricuspid annulus from the apical four-chamber view. Scanning speed was kept at $75-100 \mathrm{~m} / \mathrm{s}$ to reduce the margin of error. TDI was used to calculate the tricuspid lateral annular systolic velocity ( $\mathrm{S}^{\prime}$ tricuspid) from the apical four-chamber view. RV dysfunction was defined by TAPSE $<17 \mathrm{~mm}$ and/or S' tricuspid < $9.5 \mathrm{~cm} / \mathrm{sec} 11$. The DDimer assay was performed using an immunoassay analyzer (Radiometer AQT90 FLEX, Denmark).

The research followed the Declaration of Helsinki's values and was accepted by the institutional ethics committee (Approval date: 22/12/2020, Approval number: 2021/02-11). All participants provided informed consent.

\section{Statistical Analysis}

All statistical studies were conducted using the SPSS for Windows, v. 17.0 software package (SPSS Inc., Chicago, IL, USA). Numbers and percentages were used to represent categorical variables. Where applicable, categorical variables were compared using the chi-square or Fisher's exact test. Whether continuous variables showed a normal distribution was tested with the Kolmogorov-Smirnov test. Normally distributed continuous data were shown as median \pm SD, and non-normally distributed data as median (interquartile range). The Student's t-test was used to determine the differences between groups for continuous variables with a normal distribution. The Mann-Whitney $U$ test was used for the data that did not show a normal distribution. A value of $\mathrm{p}<0.05$ was considered statistically significant.

\section{RESULTS}

A total of 60 individuals, 30 that had recovered from COVID-19 at home and 30 age-gender matched controls, were included in the study. The baseline characteristics and laboratory parameters of the study population are listed in Table I. The mean age was $35.6 \pm 7.6$ years for the home recovery group and $35.1 \pm 6.9$ years for the control group. There were no statistical differences between the groups in terms of age, gender, heart rate, smoking, body mass index, systolic and diastolic blood pressure. Additionally, there was no statistically significant difference in laboratory parameters between the groups. 
Table I: Clinical characteristics and laboratory parameters of the study groups

\begin{tabular}{|c|c|c|c|}
\hline & $\begin{array}{l}\text { Home recovery } \\
\qquad(n=30)\end{array}$ & $\begin{array}{l}\text { Controls } \\
(n=30)\end{array}$ & p \\
\hline \multicolumn{4}{|l|}{ Baseline Demographic Parameters } \\
\hline Age, years & $35.6 \pm 7.6$ & $35.1 \pm 6.9$ & 0.806 \\
\hline Male sex, $\mathrm{n}(\%)$ & $16(53)$ & $17(57)$ & 0.795 \\
\hline Smoking, n (\%) & $7(23)$ & $10(33)$ & 0.390 \\
\hline Body mass index, $\mathrm{kg} / \mathrm{m}^{2}$ & $28.5 \pm 1.2$ & $28.6 \pm 1.2$ & 0.765 \\
\hline Systolic BP, mmHg & $126.7 \pm 5.7$ & $128.6 \pm 3.2$ & 0.233 \\
\hline Diastolic BP, $\mathrm{mmHg}$ & $75.3 \pm 4.6$ & $77.3 \pm 3.5$ & 0.080 \\
\hline Heart rate, beats per minute & $76[80-72]$ & $72[80-71]$ & 0.101 \\
\hline Time elapsed since COVID-19 diagnosis, days & $39[60-26]$ & - & - \\
\hline \multicolumn{4}{|l|}{ Laboratory Parameters } \\
\hline Hemoglobin, $\mathrm{g} / \mathrm{dL}$ & $13.5 \pm 1.2$ & $13.9 \pm 0.9$ & 0.079 \\
\hline Platelet count, $\times 10^{3} / \mu \mathrm{L}$ & $333.4 \pm 73.1$ & $312.7 \pm 74.9$ & 0.284 \\
\hline White blood cell count, $\times 10^{3} / \mu \mathrm{L}$ & $6.9[7.5-5.7]$ & $6.8[7.2-6.4]$ & 0.625 \\
\hline C-reactive protein, $\mathrm{mg} / \mathrm{dL}$ & $0.2[0.3-0.2]$ & $0.2[0.2-0.2]$ & 0.052 \\
\hline D-Dimer, $\mu \mathrm{g} / \mathrm{L}$ & $355[420-248]$ & $313[386-246]$ & 0.484 \\
\hline
\end{tabular}

BP; blood pressure, COVID-19; coronavirus disease 2019.

The RV and LV echocardiographic findings of both groups are presented in Table II. As compared to the controls, S' tricuspid was lower in the home recovery group (1314-11 vs. $144^{15-13}$; $\mathrm{p}=0.010)$. TR velocity, sPAP, TAPSE, and RV dimension were similar between the groups. Furthermore, there was no statistically significant difference in LV systolic and diastolic functions between the groups. 
Table II: Echocardiographic parameters of the study groups

\begin{tabular}{|c|c|c|c|}
\hline & $\begin{array}{l}\text { Home recovery } \\
\qquad(n=30)\end{array}$ & $\begin{array}{l}\text { Controls } \\
(n=30)\end{array}$ & $p$ \\
\hline \multicolumn{4}{|l|}{ LV assessment } \\
\hline LV ejection fraction, $\%$ & $56.6 \pm 2.2$ & $56.4 \pm 1.5$ & 0.731 \\
\hline LVEDD, mm & $46.9 \pm 3.1$ & $46.3 \pm 3.6$ & 0.493 \\
\hline LVESD, $\mathrm{mm}$ & $31.9 \pm 3.3$ & $30.9 \pm 1.7$ & 0.132 \\
\hline IVS, mm & $9.8 \pm 1.0$ & $9.5 \pm 1.0$ & 0.059 \\
\hline $\mathrm{PW}, \mathrm{mm}$ & $9.4 \pm 1.0$ & $9.0 \pm 0.9$ & 0.162 \\
\hline Left atrial diameter , cm & $32.5 \pm 2.4$ & $33.4 \pm 1.8$ & 0,122 \\
\hline E wave, $\mathrm{cm} / \mathrm{sec}$ & $72.1 \pm 13.3$ & $76.8 \pm 18.9$ & 0,277 \\
\hline A wave, $\mathrm{cm} / \mathrm{sec}$ & $50[60-46]$ & $52[62-42]$ & 0.923 \\
\hline $\mathrm{E} / \mathrm{A}$ & $1.5[1.5-1.3]$ & $1.5[1.7-1.3]$ & 0.231 \\
\hline $\mathrm{e}^{\prime}$ septal, cm/sec & $11.1 \pm 3.1$ & $11.9 \pm 2.6$ & 0.290 \\
\hline a' septal, cm/sec & $8.7 \pm 2.1$ & $8.5 \pm 1.6$ & 0.581 \\
\hline $\mathrm{S}^{\prime}$ septal, $\mathrm{cm} / \mathrm{sec}$ & $8.5[10.0-8.0]$ & $9.5[10.0-7.0]$ & 0.120 \\
\hline E/e' septal & $6.9 \pm 1.8$ & $6.5 \pm 1.3$ & 0.385 \\
\hline MAPSE Septal, cm & $11.1 \pm 2.6$ & $10.6 \pm 2.3$ & 0.445 \\
\hline $\mathrm{e}^{\prime}$ lateral, $\mathrm{cm} / \mathrm{sec}$ & $14.2 \pm 3.4$ & $15.0 \pm 2.5$ & 0.302 \\
\hline $\mathrm{a}^{\prime}$ lateral, cm/sec & $10[10-8]$ & 10 [12-9] & 0.080 \\
\hline $\mathrm{S}^{\prime}$ lateral, $\mathrm{cm} / \mathrm{sec}$ & $10[11-9]$ & $10[13-9]$ & 0.177 \\
\hline E/e' lateral & $5[6-4]$ & $5[6-4]$ & 0.751 \\
\hline MAPSE lateral, $\mathrm{cm}$ & $12.7 \pm 3.6$ & $11.8 \pm 2.5$ & 0.288 \\
\hline \multicolumn{4}{|l|}{ RV assessment } \\
\hline TAPSE, mm & $22[24-20]$ & $22[24-21]$ & 0.420 \\
\hline TR velocity, $\mathrm{m} / \mathrm{sec}$ & $1.5[1.7-1.4]$ & $1.6[1.8-1.3]$ & 0.911 \\
\hline $\mathrm{S}^{\prime}$ tricuspid, $\mathrm{cm} / \mathrm{sec}$ & $13[14-11]$ & $14[15-13]$ & 0.010 \\
\hline $\mathrm{sPAP}, \mathrm{mm} \mathrm{Hg}$ & $17.1 \pm 4.1$ & $15.9 \pm 5.1$ & 0.335 \\
\hline $\mathrm{RV}$ basal dimension, $\mathrm{mm}$ & $39[40-36]$ & 39 [39-38] & 0.237 \\
\hline
\end{tabular}


A; mitral late diastolic velocity, a'; LV myocardial late diastolic velocity, E; mitral early diastolic velocity, $e^{\prime}$; LV myocardial early diastolic velocity; IVS: inter ventricular septum, LV; left ventricular, LVEDD; LV end-diastolic dimension, LVESD; LV end-systolic dimension; MAPSE; mitral annular plane systolic excursion, RV; right ventricular, sPAP; pulmonary artery pressure systolic, PW; posterior wall, $S^{\prime}: L V$ systolic myocardial velocity, $S^{\prime}$ tricuspid; peak systolic tricuspid annular velocity, TAPSE, tricuspid annular plane systolic excursion, TR; tricuspid regurgitation.

\section{DISCUSSION}

In this single-center, prospective crosssectional study, we performed the echocardiographic examination in patients who had an outpatient COVID-19 infection and recovered from the disease at home within the last three months to determine whether there was any cardiac involvement in the acute period after infection. According to our results, the S' tricuspid value, which shows RV systolic function, was lower in patients recovering from COVID-19 at home compared to the control group. However, LV function was similar between the two groups.

COVID-19 has been reported to have a mild course in $80 \%$ of patients, a severe course requiring hospitalization in $15 \%$, and a critically severe course requiring intensive care in 5\% ${ }^{1}$. Transthoracic echocardiography is widely used to measure the right and left heart dimensions and evaluate ventricular diastolic and systolic function. It is known that both RV and LV involvements due to COVID-19 occur in hospitalized patients during their hospital stay ${ }^{12}$. In a large retrospective study involving 1,216 inpatients, $55 \%$ were found to have abnormal echocardiography findings 4 . The assessment of RV by echocardiography function is still difficult given the complex geometry of the RV. While echocardiographic parameters of $\mathrm{RV}$ function such as fractional area change (FAC) and EF are theoretically good measurement proxy, their clinical utility is limited due to the suboptimal endocardial border ${ }^{13}$. Therefore, in the current study, rather than measuring FAC and RVEF values, we investigated the TAPSE and S'tricuspid parameters. The TAPSE measurement is considered to provide quantitative information about RV systolic function and show a good correlation with RVEF based on the idea that the majority of RV movement is through subendocardial myocardial fibers located longitudinally in the RV wall, and thus the tricuspid annulus movement between the annular plane and the apex on the long axis can indicate global RV function ${ }^{8,9}$. In addition, a TAPSE value below $17 \mathrm{~mm}$ indicates impaired RV systolic function ${ }^{11}$. S' tricuspid formed during systolic ejection is used to evaluate RV systolic function. This value being less than 9.5 $\mathrm{cm} / \mathrm{sec}$ is interpreted as RV dysfunction ${ }^{11}$.

It has been observed that reduced TAPSE in patients hospitalized due to COVID-19 is an independent predictor of in-hospital mortality $^{9,14}$. In a meta-analysis involving 641 patients with COVID-19, each 1-mm reduction in TAPSE resulted in an approximately $20 \%$ increase in mortality ${ }^{15}$. In contrast, there are also publications reporting no relationship between TAPSE and in-hospital mortality. Pagnesi et al. ${ }^{16}$ reported that RV dysfunction (decreased TAPSE or S' tricuspid) developed in $14 \%$ of patients admitted to non-intensive care departments with the diagnosis of COVID-19, and sPAP was $>35 \mathrm{~mm} \mathrm{Hg}$ in $12 \%$. The authors also noted that SPAP, not TAPSE, was associated with an adverse outcome. In another study, Jarori et al.6 stated that there was no relationship between TAPSE and mortality in hospitalized patients. There are only a few studies on TAPSE and $S^{\prime}$ tricuspid values in patients that have recovered from the disease at home. Ozer et al. ${ }^{17}$ did not find any difference in the TAPSE and S' tricuspid values between the three groups (control group, patients that recovered at home, and those that recovered after hospitalizations). Furthermore, they found that the RV diameter was larger in the hospital 
recovery group than the controls. In that study, echocardiographic examinations were performed on average 133 days after recovery from the disease. In the current study, compared with the control group, the patients who had recovered from COVID-19 at home did not have significantly different TAPSE, sPAP, TR velocity, and RV dimension values. Although the $S^{\prime}$ tricuspid velocity values showing RV systolic function were lower in the COVID-19 group, they were still within the normal reference range. The lack of a difference in the RV function between the two groups may have resulted from the absence of RV afterload and RV dilatation since the patients had a mild form of the disease that did not cause moderate-severe pulmonary involvement or it may be related to the evaluation of only patients that had recovered from the disease.

SARS-CoV-2 can have direct cytotoxic effects on the myocardium through the angiotensinconverting enzyme 2 receptor found in myocardial cells. In addition, cytokine storm during infection, microthrombogenesis, rupture of atherosclerotic plaques, increased stress, and increased sympathetic activity can lead to systolic dysfunction and heart failure by causing myocardial damage ${ }^{18}$. MAPSE, which is used to evaluate longitudinal LV systolic function, is an early indicator of myocardial disease. In a study conducted with patients hospitalized with a diagnosis of COVID-19, although there was no difference in LVEF and LV diastolic dysfunction (E/a') between those that died and those that survived, it was reported that MAPSE was lower in the former, and it was an independent predictor of mortality ${ }^{6}$. In a study including patients who had been hospitalized with a diagnosis of mild to moderate COVID-19 pneumonia and discharged, who had no known history of cardiovascular disease, echocardiography was performed in the postacute COVID phase ( $<12$ weeks), and LV dysfunction was detected in $8.8 \%$ of patients and diastolic dysfunction in $16.8 \%{ }^{19}$. In another study, patients hospitalized with a diagnosis of COVID-19 and discharged underwent echocardiography one month after the first detection of infection, and the RV and LV functions did not vary between the control and patient groups ${ }^{20}$. In a study, echocardiography was performed an average of 41 days after patients were discharged12. It was reported that the LV and RV functions were similar between the patients whose cardiac troponin value increased during hospitalization and those whose troponin value did not increase. Our study is the first to show that MAPSE, an early marker of LV systolic function in the postacute COVID phase, is similar between patients who have completed home treatment and healthy controls. We also determined that the diastolic function of LV, LVEF and LV was similar among the two groups.

The current research has some limitations. It was an observational single-center study involving small number of patients. In addition, 2D speckle-tracking echocardiography handled to ensure global and regional longitudinal strain (GLS) or three-dimensional echocardiography was not performed for RV and LV systolic functions.

\section{CONCLUSION}

In this echocardiographic study, patients that had recovered from COVID-19 at home had a reduced $S^{\prime}$ tricuspid value, an indicator of RV systolic function in the post-acute COVID phase. However, this value was still within the normal range. Larger studies involving a higher number of participants are needed to determine whether subclinical RV dysfunction develops in patients recovering from the disease at home. Prospective studies with larger sample size will be required to verify the results of our study.

Ethical approval: The Adiyaman University Ethics Committee on Human Research (Approval date: 22/12/2020, Approval 
number: 2021/02-11) and the Turkish Ministry of Health approved the study protocol.

Conflict of Interest: No conflict of interest was declared by the authors.

Financial Disclosure: No financial disclosure was declared by the authors.

\section{REFERENCES}

1. Görmeli Kurt N, Çamcı M. COVID-19 and Other Viral Pneumonias. Dicle Med J. 2021; 48: 40-46.

2. Kwenandar F, Japar KV, Damay V, et al. Coronavirus disease 2019 and cardiovascular system: A narrative review. Int J Cardiol Heart Vasc. 2020; 29: 100557.

3. Chang WT, Toh HS, Liao CT, et al. Cardiac Involvement of COVID-19: A Comprehensive Review. Am J Med Sci. 2021; 361: 14-22.

4. Dweck MR, Bularga A, Hahn RT, et al. Global evaluation of echocardiography in patients with COVID-19. Eur Heart J Cardiovasc Imaging. 2020; 21: 949-58.

5. Szekely Y, Lichter Y, Taieb P, et al. Spectrum of Cardiac Manifestations in COVID-19: A Systematic Echocardiographic Study. Circulation. 2020; 142: 342-53.

6. Jarori U, Maatman TK, Maatman B, et al. Mitral Annular Plane Systolic Excursion: An Early Marker of Mortality in Severe COVID-19. J Am Soc Echocardiogr. 2020; 33: 1411-13.

7. Modin D, Møgelvang R, Andersen DM, BieringSørensen T. Right Ventricular Function Evaluated by Tricuspid Annular Plane Systolic Excursion Predicts Cardiovascular Death in the General Population. J Am Heart Assoc. 2019; 8: e012197.

8. Schmid E, Hilberath JN, Blumenstock G, et al. Tricuspid annular plane systolic excursion (TAPSE) predicts poor outcome in patients undergoing acute pulmonary embolectomy. Heart Lung Vessel. 2015; 7: 151-58.

9. Lassen $\mathrm{MCH}$, Skaarup $\mathrm{KG}$, Lind JN, et al. Echocardiographic abnormalities and predictors of mortality in hospitalized COVID-19 patients: the ECHOVID-19 study. ESC Heart Fail. 2020; 7: 418997.
10. Nagueh SF, Smiseth OA, Appleton CP, et al. Recommendations for the Evaluation of Left Ventricular Diastolic Function by Echocardiography: An Update from the American Society of Echocardiography and the European Association of Cardiovascular Imaging. J Am Soc Echocardiogr. 2016; 29: 277-314.

11. Lang RM, Badano LP, Mor-Avi V, et al. Recommendations for Cardiac Chamber Quantification by Echocardiography in Adults: An Update from the American Society of Echocardiography and the European Association of Cardiovascular Imaging. J Am Soc Echocardiogr. 2015; 28: 1-39.

12. Catena C, Colussi G, Bulfone L, et al. Echocardiographic comparison of COVID-19 patients with or without prior biochemical evidence of cardiac injury after recovery. J Am Soc Echocardiogr. 2020; 20: 30666.

13. Wu VC, Takeuchi M. Echocardiographic assessment of right ventricular systolic function. Cardiovasc Diagn Ther. 2018; 8: 70-9.

14. Li Y, Li H, Zhu S, et al. Prognostic Value of Right Ventricular Longitudinal Strain in Patients With COVID-19. JACC Cardiovasc Imaging. 2020; 13: 2287-99.

15. Martha JW, Pranata R, Wibowo A, et al. Tricuspid annular plane systolic excursion (TAPSE) measured by echocardiography and mortality in COVID-19: A systematic review and meta-analysis. Int J Infect Dis. 2021; 105: 351-56.

16. Pagnesi M, Baldetti L, Beneduce A, et al. Pulmonary hypertension and right ventricular involvement in hospitalised patients with COVID-19. Heart. 2020; 106: 1324-31.

17. Ozer PK, Govdeli EA, Baykiz D, et al. Impairment of right ventricular longitudinal strain associated with severity of pneumonia in patients recovered from COVID-19. Int J Cardiovasc Imaging. 2021; 11: 1-11.

18. Madjid M, Safavi-Naeini P, Solomon SD, et al. Potential Effects of Coronaviruses on the Cardiovascular System: A Review. JAMA Cardiol. 2020; 5: 831-40. 
19. Tudoran M, Tudoran C, Lazureanu VE, et al. Alterations of Left Ventricular Function Persisting during Post-Acute COVID-19 in Subjects without Previously Diagnosed Cardiovascular Pathology. J. Pers. Med. 2021; 11: 225.
20. Sechi LA, Colussi G, Bulfone L, et al. Short-term cardiac outcome in survivors of COVID-19: a systematic study after hospital discharge. Clin Res Cardiol. 2021; 22: 1-10. 